Supporting Information

\title{
Thermodynamic and Kinetic Influence of Oxygen Vacancies on the Solar Water Oxidation Reaction of $\alpha-\mathrm{Fe}_{2} \mathrm{O}_{3}$ Photoanode
}

Qian Yang, ${ }^{\dagger}$ Jinyan Du, ${ }^{\dagger}$ Jie Li, ${ }^{\dagger}$ Yuting Wu, ${ }^{\dagger}$ Yong Zhou, ${ }^{\ddagger}$ Yang Yang, ${ }^{\S}$ Dingming Yang, ${ }^{\dagger *}$ and Huichao He ${ }^{\dagger *}$

${ }^{\dagger}$ State Key Laboratory of Environmental-Friendly Energy Materials, School of Materials Science and Engineering, Southwest University of Science and Technology, Mianyang 621010, China.

Ecomaterials and Renewable Energy Research Center, School of Physics, Nanjing University, Nanjing 211102, China.

${ }^{\S}$ College of Chemistry and Chemical Engineering, Shannxi University of Science \& Technology, Xi'an 710021, China.

*Corresponding Authors’ Email: hehuichao@swust.edu.cn (Huichao He); yangdingming@swust.edu.cn (Dingming Yang) 
Table S1 FWHM of Raman peaks for the pristine $\alpha-\mathrm{Fe}_{2} \mathrm{O}_{3}$ and the $\alpha-\mathrm{Fe}_{2} \mathrm{O}_{3}(\mathrm{OV}-120 \mathrm{~min})$ film.

\begin{tabular}{ccc}
\hline & \multicolumn{2}{c}{ FWHM of Raman peaks } \\
\cline { 2 - 3 } Wavelength & $\alpha-\mathrm{Fe}_{2} \mathrm{O}_{3}$ & $\alpha-\mathrm{Fe}_{2} \mathrm{O}_{3}(\mathrm{OV}-120 \mathrm{~min})$ \\
\hline $225 \mathrm{~cm}^{-1}$ & 9.03666 & 9.91492 \\
$247 \mathrm{~cm}^{-1}$ & 8.88052 & 9.01087 \\
$293 \mathrm{~cm}^{-1}$ & 16.44633 & 19.79595 \\
$412 \mathrm{~cm}^{-1}$ & 13.32985 & 21.42905 \\
$498 \mathrm{~cm}^{-1}$ & 20.64318 & 22.12221 \\
$613 \mathrm{~cm}^{-1}$ & 15.84654 & 20.29509 \\
$660 \mathrm{~cm}^{-1}$ & & 22.25651 \\
\hline
\end{tabular}



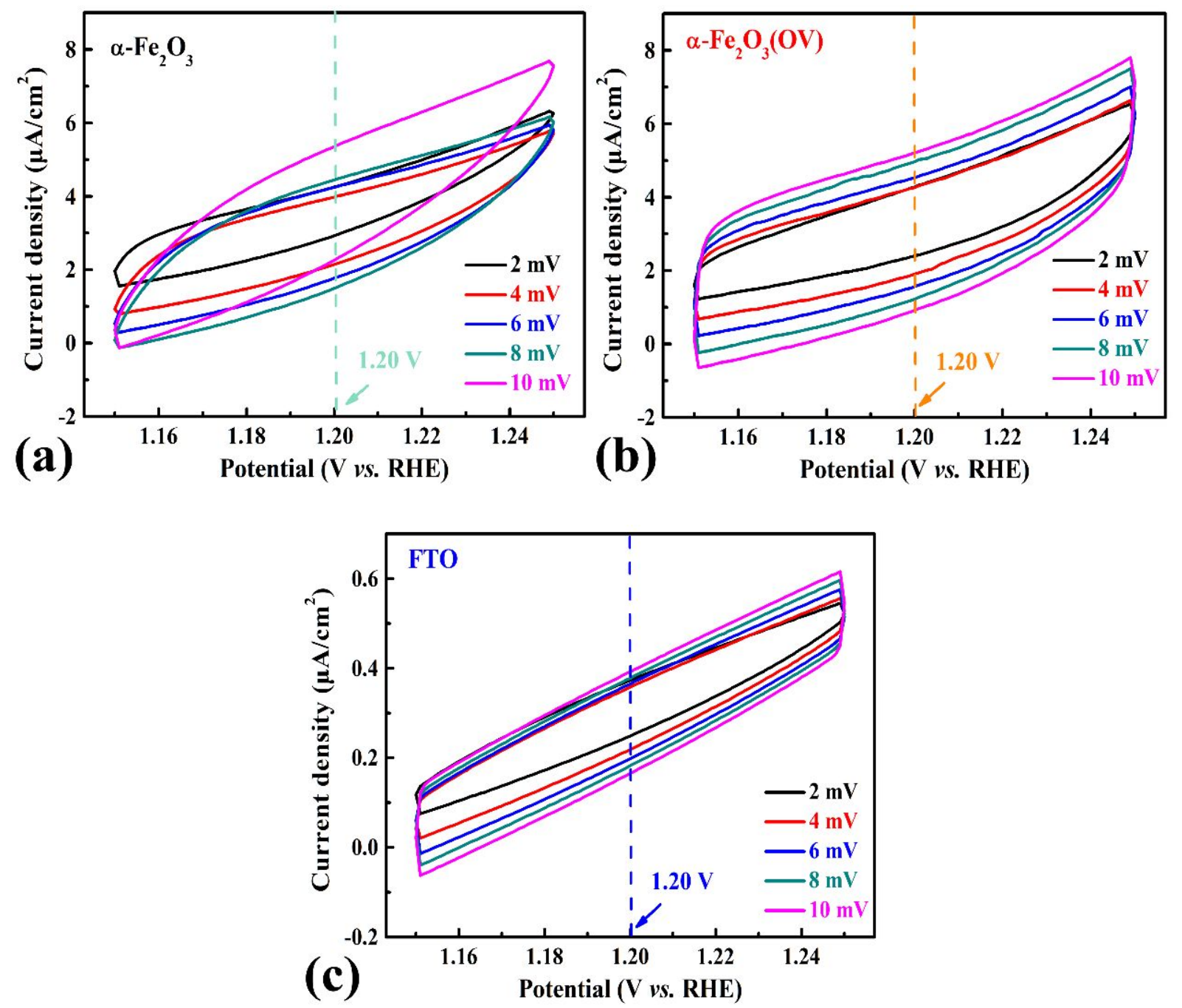

Figure S1 CV curves of the (a) pristine $\alpha-\mathrm{Fe}_{2} \mathrm{O}_{3}$ film, (b) the $\alpha-\mathrm{Fe}_{2} \mathrm{O}_{3}(\mathrm{OV}-120 \mathrm{~min})$ film and (c) the FTO substrate in a non-Faradaic region (from $1.15 \mathrm{~V}$ to $1.25 \mathrm{~V} v s$. RHE) at a series of scan rates of 2, 4, 6, 8 and $10 \mathrm{mV} / \mathrm{s}$ in $1.0 \mathrm{M} \mathrm{NaOH}$. 

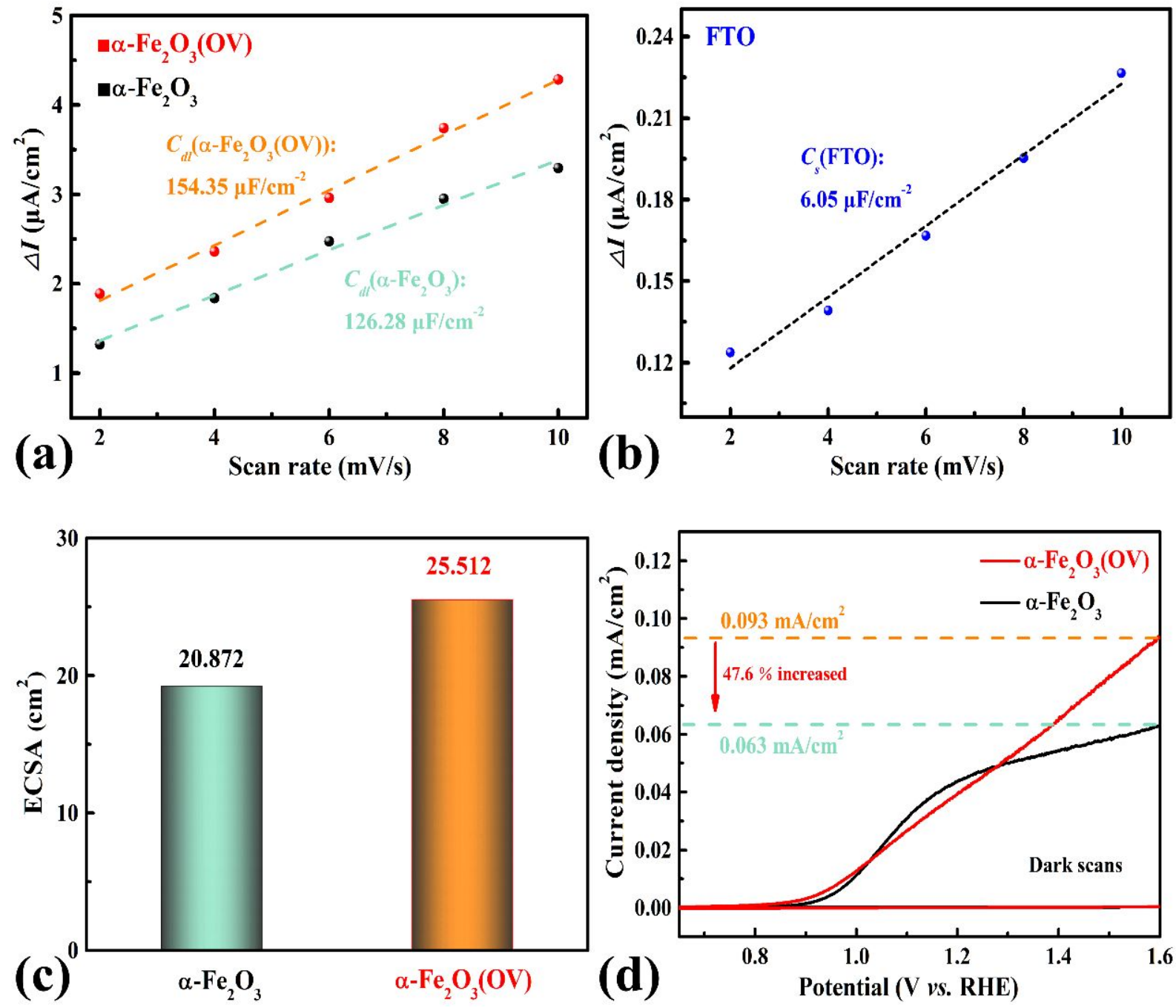

Figure S2 (a) The $\Delta I \sim v$ plots of the pristine $\alpha-\mathrm{Fe}_{2} \mathrm{O}_{3}$ film and the $\alpha-\mathrm{Fe}_{2} \mathrm{O}_{3}(\mathrm{OV}-120 \mathrm{~min})$ film for the determination of their double-layer capacitance $\left(C_{d l}\right)$ at $1.2 \mathrm{~V} v s$. RHE. (b) The $\Delta I \sim v$ plots of FTO substance for the determination of special capacitance $\left(C_{S}\right)$ at $1.2 \mathrm{~V} v s$. RHE. (c) The ECSA for the pristine $\alpha-\mathrm{Fe}_{2} \mathrm{O}_{3}$ film and the $\alpha-\mathrm{Fe}_{2} \mathrm{O}_{3}(\mathrm{OV}-120 \mathrm{~min})$ film. (d) ECSA-normalized photocurrent density for the pristine $\alpha-\mathrm{Fe}_{2} \mathrm{O}_{3}$ film and the $\alpha-\mathrm{Fe}_{2} \mathrm{O}_{3}(\mathrm{OV}-120 \mathrm{~min})$ film. 

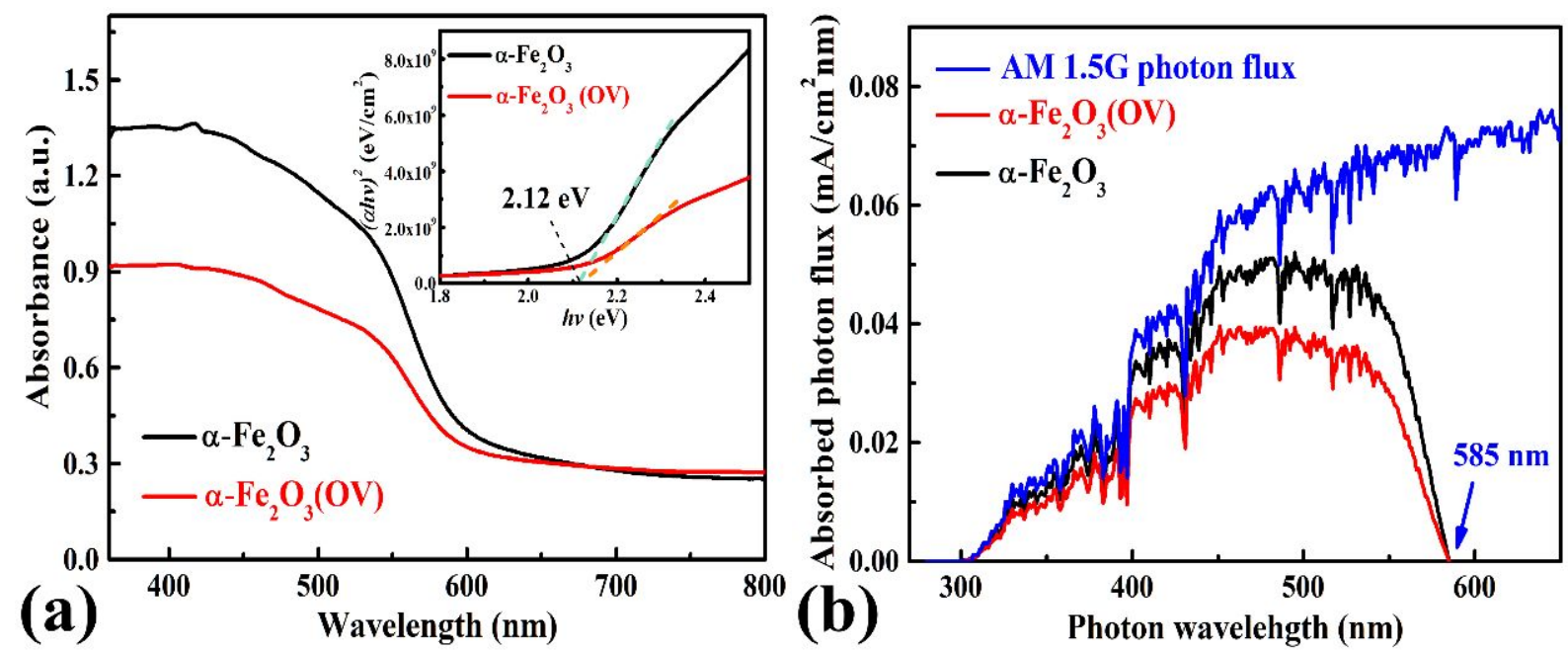

Figure S3 (a) UV-vis absorbance spectrum of the pristine $\alpha-\mathrm{Fe}_{2} \mathrm{O}_{3}$ film and the $\alpha-\mathrm{Fe}_{2} \mathrm{O}_{3}(\mathrm{OV}-120 \mathrm{~min})$ film (Inset: Tauc plots of the as-prepared films). (b) Absorbed photon flux of the pristine $\alpha-\mathrm{Fe}_{2} \mathrm{O}_{3}$ film and the $\alpha-\mathrm{Fe}_{2} \mathrm{O}_{3}(\mathrm{OV}-120 \mathrm{~min})$ film. 

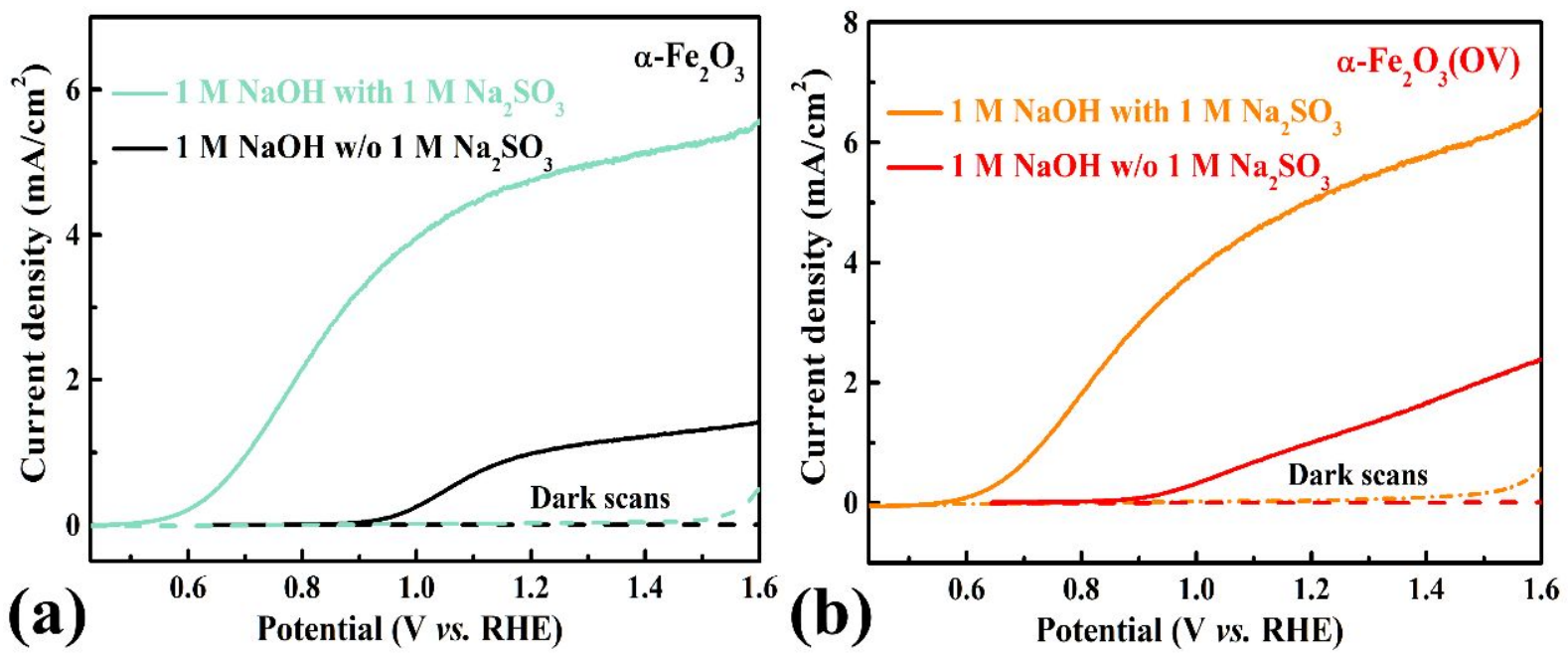

Figure S4 LSV scans for the (a) pristine $\alpha-\mathrm{Fe}_{2} \mathrm{O}_{3}$ film and the (b) $\alpha-\mathrm{Fe}_{2} \mathrm{O}_{3}(\mathrm{OV}-120 \mathrm{~min})$ film in $1.0 \mathrm{M}$ $\mathrm{NaOH}$ with and without $1.0 \mathrm{M} \mathrm{Na}_{2} \mathrm{SO}_{3}$ under $\mathrm{AM} 1.5 \mathrm{G}$ illumination. 


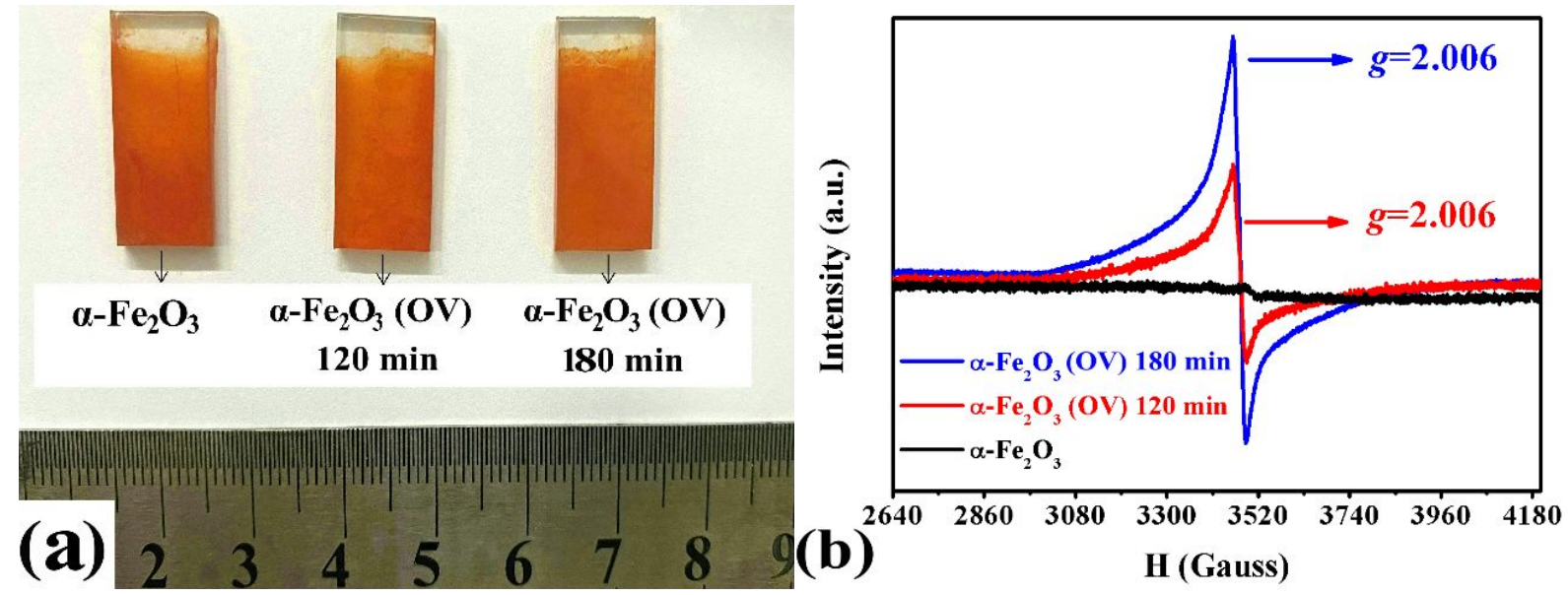

Figure S5 (a) Photographs of the pristine $\alpha-\mathrm{Fe}_{2} \mathrm{O}_{3}$ film and the hydrothermally treated $\alpha-\mathrm{Fe}_{2} \mathrm{O}_{3}$ films (120 and $180 \mathrm{~min}$ ). (b) EPR spectra of the pristine $\alpha-\mathrm{Fe}_{2} \mathrm{O}_{3}$ film and the hydrothermally treated $\alpha-\mathrm{Fe}_{2} \mathrm{O}_{3}$ films (120 and $180 \mathrm{~min})$. 


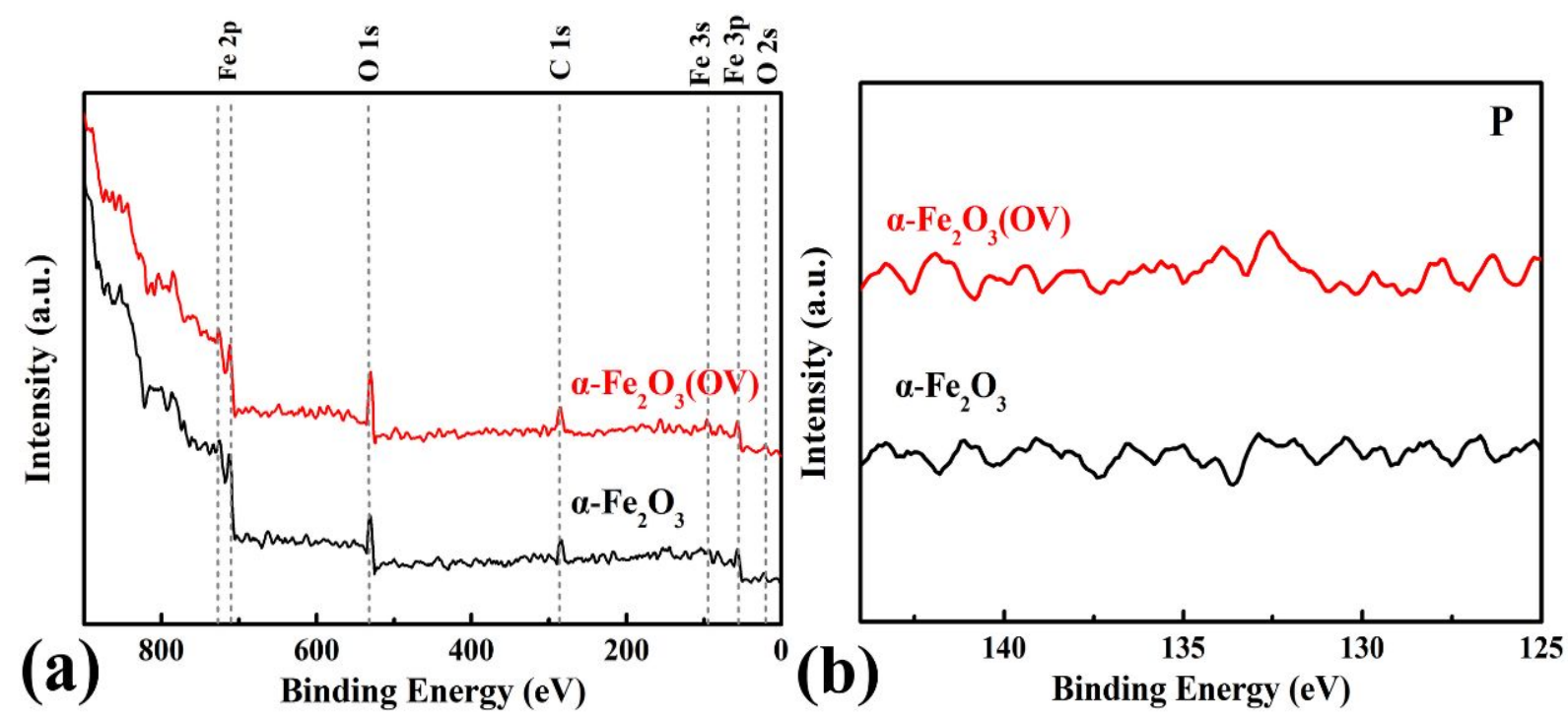

Figure S6 (a) XPS survey spectrum of the pristine $\alpha-\mathrm{Fe}_{2} \mathrm{O}_{3}$ film and the $\alpha-\mathrm{Fe}_{2} \mathrm{O}_{3}(\mathrm{OV}-120 \mathrm{~min})$ film. (b) The XPS signals collected from the pristine $\alpha-\mathrm{Fe}_{2} \mathrm{O}_{3}$ film and the $\alpha-\mathrm{Fe}_{2} \mathrm{O}_{3}(\mathrm{OV}-120 \mathrm{~min})$ film range from 125 to $148 \mathrm{eV}$ that correspond to the typical XPS signal of $\mathrm{P}_{2 \mathrm{p}}$. 

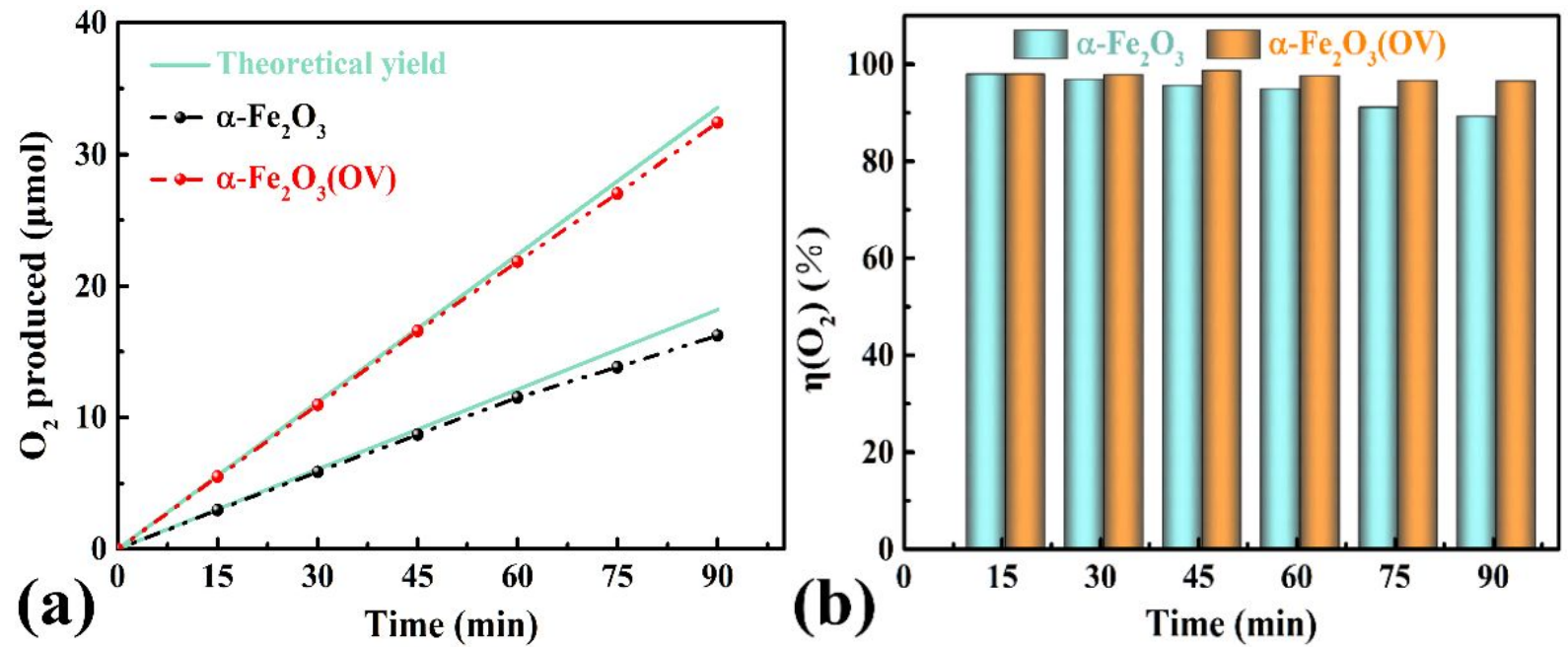

Figure $\mathbf{S} 7$ (a) The $\mathrm{O}_{2}$ generation amount and (b) Faradaic efficiency for the pristine $\alpha-\mathrm{Fe}_{2} \mathrm{O}_{3}$ film and the $\alpha-\mathrm{Fe}_{2} \mathrm{O}_{3}(\mathrm{OV}-120 \mathrm{~min})$ film photoanode in $1.0 \mathrm{M} \mathrm{NaOH}$ under $\mathrm{AM} 1.5 \mathrm{G}$ illumination. 

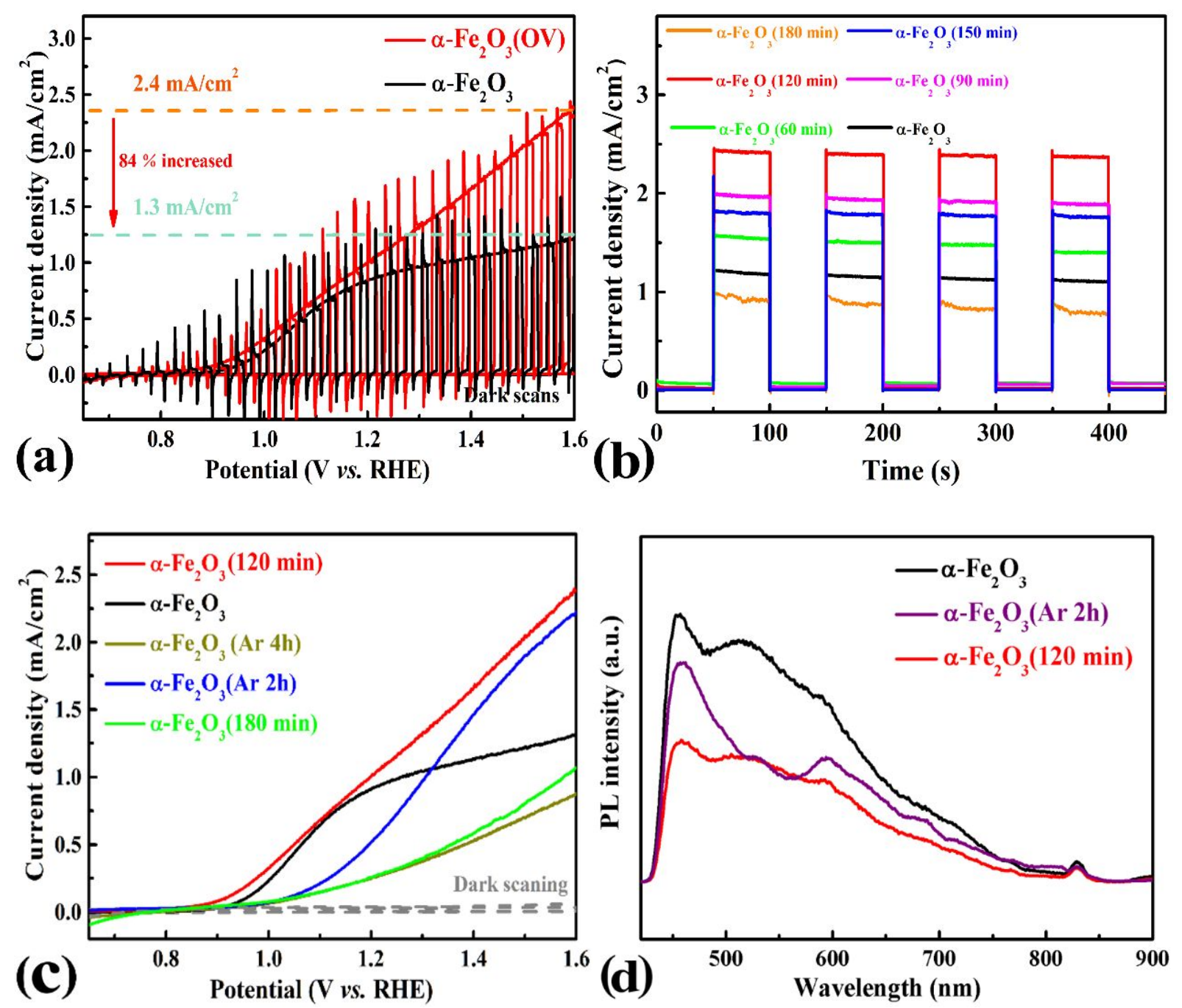

Figure S8 (a) LSV curves for the pristine $\alpha-\mathrm{Fe}_{2} \mathrm{O}_{3}$ film and the $\alpha-\mathrm{Fe}_{2} \mathrm{O}_{3}(\mathrm{OV}-120 \mathrm{~min})$ film in $1.0 \mathrm{M}$ $\mathrm{NaOH}$ under chopped AM $1.5 \mathrm{G}$ illumination. (b) $j-t$ curves of the pristine $\alpha-\mathrm{Fe}_{2} \mathrm{O}_{3}$ film and the hydrothermally treated $\alpha-\mathrm{Fe}_{2} \mathrm{O}_{3}$ films at $1.6 \mathrm{~V}$ vs. RHE in $1.0 \mathrm{M} \mathrm{NaOH}$ under chopped AM 1.5G illumination. (c) LSV curves for the pristine $\alpha-\mathrm{Fe}_{2} \mathrm{O}_{3}$ film and the $\alpha-\mathrm{Fe}_{2} \mathrm{O}_{3}$ film that be treated in argon atmosphere at $600{ }^{\circ} \mathrm{C}$ (for 2 and $4 \mathrm{~h}$ ) or in $\mathrm{NaH}_{2} \mathrm{PO}_{2}$ aqueous solution at $100{ }^{\circ} \mathrm{C}$ for hydrothermal reaction (120 and $180 \mathrm{~min}$ ). (d) PL spectrum for the pristine $\alpha-\mathrm{Fe}_{2} \mathrm{O}_{3}$ film and the $\alpha-\mathrm{Fe}_{2} \mathrm{O}_{3}$ film that be treated in argon atmosphere at $600{ }^{\circ} \mathrm{C}$ for $2 \mathrm{~h}$ or in $\mathrm{NaH}_{2} \mathrm{PO}_{2}$ aqueous solution for $120 \mathrm{~min}$ of hydrothermal reaction. 


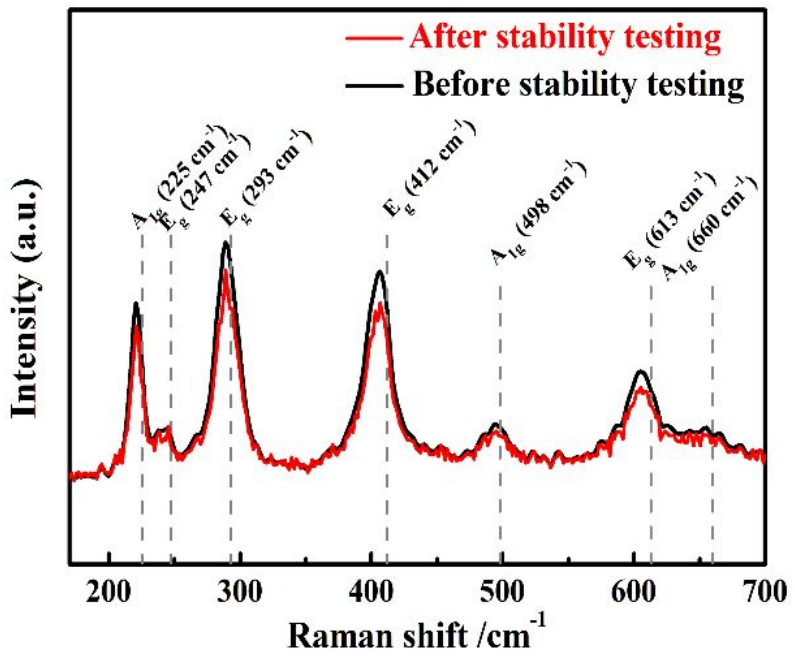

Figure S9 Raman spectra of the $\alpha-\mathrm{Fe}_{2} \mathrm{O}_{3}(\mathrm{OV}-120 \mathrm{~min})$ film before and after 3 hours of stability testing in $1.0 \mathrm{M} \mathrm{NaOH}$ at $1.6 \mathrm{~V} v s$. RHE under AM $1.5 \mathrm{G}$ illunimation. 


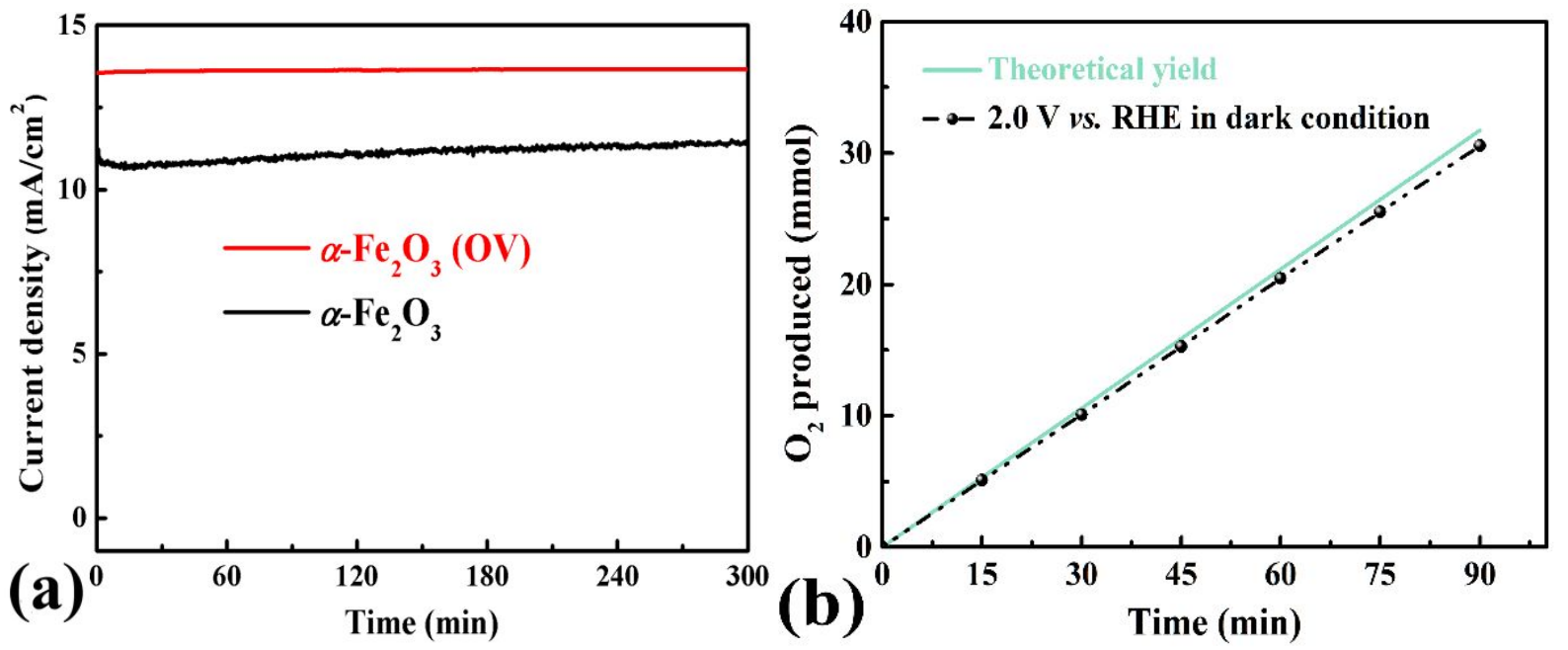

Figure $\mathrm{S10}$ (a) $j$ - $t$ curves of the pristine $\alpha-\mathrm{Fe}_{2} \mathrm{O}_{3}$ film and the $\alpha-\mathrm{Fe}_{2} \mathrm{O}_{3}(\mathrm{OV}-120 \mathrm{~min})$ film electrode during 5 hours of electrochemical water oxidation in $1.0 \mathrm{M} \mathrm{NaOH}$ at $2.0 \mathrm{~V} v s$. RHE. (b) The $\mathrm{O}_{2}$ generation amount and Faradaic efficiency for the $\alpha-\mathrm{Fe}_{2} \mathrm{O}_{3}(\mathrm{OV}-120 \mathrm{~min})$ film electrode in $1.0 \mathrm{M} \mathrm{NaOH}$ at $2.0 \mathrm{~V} v s$. RHE. 


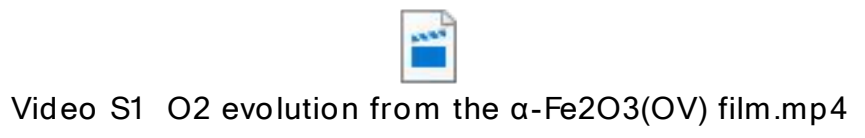

Video $\mathrm{S} 1 \mathrm{O}_{2}$ evolution from the $\alpha-\mathrm{Fe}_{2} \mathrm{O}_{3}(\mathrm{OV}-120 \mathrm{~min})$ film at $2.0 \mathrm{~V} v \mathrm{~s}$. RHE in dark condition. 
Table S2 The value of elements in equivalent circuit fitted in the Nyquist Plots for the pristine $\alpha-\mathrm{Fe}_{2} \mathrm{O}_{3}$ and $\alpha-\mathrm{Fe}_{2} \mathrm{O}_{3}(\mathrm{OV})$ film.

\begin{tabular}{cccccc}
\hline Samples & $\begin{array}{c}\mathrm{R}_{\mathrm{s}} / \Omega \\
(\text { error/\%) }\end{array}$ & $\begin{array}{c}\mathrm{CPE}_{\text {bulk }} / \mathrm{F} \\
(\text { error } / \%)\end{array}$ & $\begin{array}{c}\mathrm{R}_{\text {trap }} / \Omega \\
(\text { error } / \%)\end{array}$ & $\begin{array}{c}\mathrm{R}_{\mathrm{ct}} / \Omega \\
(\text { error } / \%)\end{array}$ & $\begin{array}{c}\text { CPEss/F } \\
(\text { error/ \%) }\end{array}$ \\
\hline$\alpha-\mathrm{Fe}_{2} \mathrm{O}_{3}$ & 9.302 & $7.934 \mathrm{E}-6$ & 105.7 & $4.896 \mathrm{E}-5$ & 295.7 \\
& $(2.64 \%)$ & $(3.91 \%)$ & $(5.86 \%)$ & $(5.86 \%)$ & $(3.46 \%)$ \\
$\alpha-\mathrm{Fe}_{2} \mathrm{O}_{3}(\mathrm{OV})$ & 9.402 & $1.029 \mathrm{E}-5$ & 97.89 & $4.432 \mathrm{E}-5$ & 273.1 \\
& $(2.11 \%)$ & $(3.27 \%)$ & $(5.20 \%)$ & $(7.17 \%)$ & $(3.75 \%)$ \\
\hline
\end{tabular}



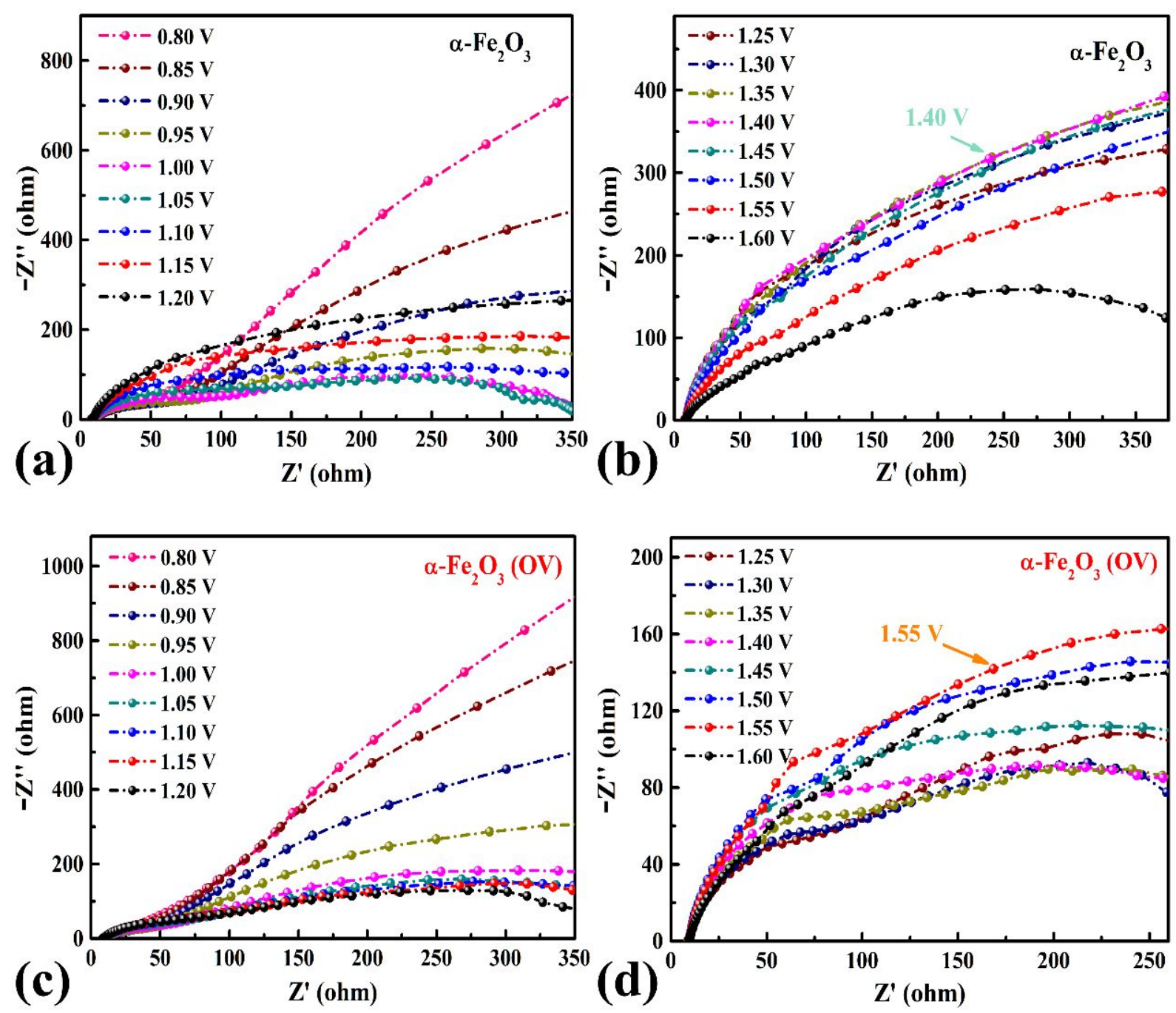

Figure S11 Nyquist plots of the (a-b) pristine $\alpha-\mathrm{Fe}_{2} \mathrm{O}_{3}$ film and the (c-d) $\alpha-\mathrm{Fe}_{2} \mathrm{O}_{3}(\mathrm{OV})$ film at a series of applied potentials in $1.0 \mathrm{M} \mathrm{NaOH}$ under $\mathrm{AM} 1.5 \mathrm{G}$ irradiation. 